\title{
Maternal administration of meclozine for the treatment of foramen magnum stenosis in transgenic mice with achondroplasia
}

\author{
Masaki Matsushita, PhD, MD,, Kenichi Mishima, PhD, MD,, ${ }^{1,2}$ Ryusaku Esaki,, \\ Naoki Ishiguro, PhD, MD, ${ }^{2}$ Kinji Ohno, PhD, MD, ${ }^{1}$ and Hiroshi Kitoh, PhD, MD ${ }^{2}$ \\ 'Division of Neurogenetics, Center for Neurological Diseases and Cancer, and 2Department of Orthopaedic Surgery, Nagoya \\ University Graduate School of Medicine, Nagoya, Japan
}

\begin{abstract}
OBJECTIVE Achondroplasia (ACH) is the most common short-limbed skeletal dysplasia caused by gain-of-function mutations in the fibroblast growth factor receptor 3 (FGFR3) gene. Foramen magnum stenosis (FMS) is one of the serious neurological complications in ACH. Through comprehensive drug screening, the authors identified that meclozine, an over-the-counter drug for motion sickness, inhibited activation of FGFR3 signaling. Oral administration of meclozine to the growing $\mathrm{ACH}$ mice promoted longitudinal bone growth, but it did not prevent FMS. In the current study, the authors evaluated the effects of maternal administration of meclozine on FMS in ACH mice.
\end{abstract}

METHODS The area of the foramen magnum was measured in 17-day-old Fgfr3ach mice and wild-type mice using micro-CT scanning. Meclozine was administered to the pregnant mice carrying Fgfr3ach offspring from embryonic Day (ED) 14.5 to postnatal Day (PD) 4.5. Spheno-occipital and anterior intraoccipital synchondroses were histologically examined, and the bony bridges were scored on PD 4.5. In wild-type mice, tissue concentrations of meclozine in ED 17.5 fetuses and PD 6.5 pups were investigated.

RESULTS The area of the foramen magnum was significantly smaller in 17-day-old Fgfr3ach mice than in wild-type mice $(p<0.005)$. There were no bony bridges in the spheno-occipital and anterior intraoccipital synchondroses in wild-type mice, while some of the synchondroses prematurely closed in untreated Fgfr3ach mice at PD 4.5. The average bony bridge score in the cranial base was $7.053 \pm 1.393$ in untreated Fgfr $3{ }^{\text {ach }}$ mice and $6.125 \pm 2.029$ in meclozine-treated Fgfr 3 ach mice. The scores were not statistically significant between mice with and those without meclozine treatment $(p=$ $0.12)$. The average tissue concentration of meclozine was significantly higher $(508.88 \pm 205.16 \mathrm{ng} / \mathrm{g})$ in PD 6.5 mice than in ED 17.5 mice $(56.91 \pm 20.05 \mathrm{ng} / \mathrm{g})(\mathrm{p}<0.005)$.

CONCLUSIONS Maternal administration of meclozine postponed premature closure of synchondroses in some Fgfrach mice, but the effect on preventing bony bridge formation was not significant, probably due to low placental transmission of the drug. Meclozine is likely to exhibit a marginal effect on premature closure of synchondroses at the cranial base in $\mathrm{ACH}$. http://thejns.org/doi/abs/10.3171/2016.7.PEDS16199

KEY WORDS foramen magnum; achondroplasia; meclozine; FGFR3; spine

$\mathrm{A}$ CHONDROPLASIA (ACH) is one of the most common skeletal dysplasias with disproportionate short stature caused by activating mutations in FGFR3 encoding the fibroblast growth factor receptor $3 .^{10,11} \mathrm{In}$ addition to rhizomelic shortening of the extremities, foramen magnum stenosis (FMS) is one of the most serious neurological complications in patients with $\mathrm{ACH}$, which sometimes results in sudden unexpected death in infants. ${ }^{9}$
Cervicomedullary decompression surgery has been indicated for infants who exhibited lower-limb hyperreflexia or clonus on examination, central hypopnea demonstrated by polysomnography, and foramen magnum measures below the mean for children with $\mathrm{ACH} .{ }^{8}$ Premature closure of spheno-occipital bone synchondrosis was confirmed by CT studies in patients with ACH. ${ }^{1}$ Partial closure of the spheno-occipital synchondrosis and anterior intraoccipital

ABBREVIATIONS ACH = achondroplasia; ED = embryonic day; FGFR3 = fibroblast growth factor receptor 3; FMS = foramen magnum stenosis; $P D=$ postnatal day . SUBMITTED April 6, 2016. ACCEPTED July 19, 2016.

INCLUDE WHEN CITING Published online October 21, 2016; DOI: 10.3171/2016.7.PEDS16199. 


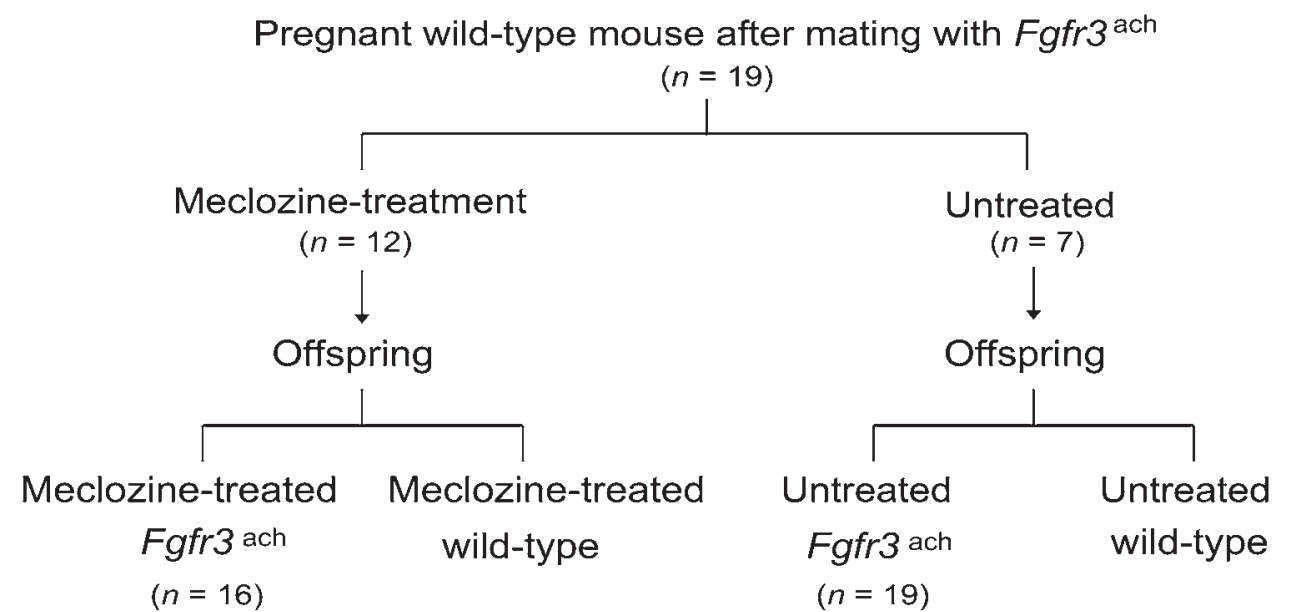

FIG. 1. Flowchart showing the number of Fgfr $3^{\text {ach }}$ mice treated with or without meclozine. Pregnant wild-type mice mated with male Fgfr3ach mice were divided into 2 groups according to drug intervention. As a result, 16 meclozine-treated and 19 untreated Fgfr 3 ach mice were used.

synchondroses was also observed in 36-week-gestation fetuses with thanatophoric dysplasia, ${ }^{5}$ which represents the most severe phenotype among FGFR3 disorders. Experimentally, Fgfr $3^{\mathrm{G} 374 \mathrm{R} /+}$ mice corresponding to human $\mathrm{ACH}$ exhibited premature closure of synchondroses at the cranial base on PD 10, while there was no evidence of fused synchondroses in wild-type littermate mice. ${ }^{5}$ Therefore, growth-promoting treatment for FMS should be initiated before closure of occipital synchondroses.

Several FGFR3-targeted treatments for ACH have been reported in recent years. Continuous intravenous administration of C-type natriuretic peptide (CNP) and CNP analog (BMN-111) was associated with significant bone growth recovery in a mouse model of $\mathrm{ACH}^{2,15}$ Using induced pluripotent stem cells established from patients with FGFR3 disorders, Yamashita et al. demonstrated that statins also rescued the dwarf phenotype in an $\mathrm{ACH}$ model in mice. ${ }^{14}$ Through comprehensive drug screening, we identified that meclozine, an antihistamine drug that has been used as an anti-motion sickness medication for more than 50 years, inhibited FGFR 3 signaling in various chondrocytic cell lines. ${ }^{4}$ In addition, meclozine increased longitudinal bone growth in an $\mathrm{ACH}$ mouse model by suppressing FGFR3 signaling. ${ }^{3}$ The effects of these FGFR3 inhibitors on FMS have not been studied in detail probably because of their postnatal administration.

For the treatment of FMS in ACH, we investigated the effects of maternally administered meclozine on premature closure of synchondroses in the cranial base in $\mathrm{ACH}$ mice.

\section{Methods \\ Mice}

Fgfr $3^{\text {ach }}$ mice (FVB/NJcl background) were provided by Dr. David M. Ornitz at Washington University in St. Louis. ${ }^{7}$ In brief, $F g f r 3^{\text {ach }}$ mice express activated $F G F R 3$ in the growth plate using the Col2al promoter. In all experiments, we used transgenic mice carrying the heterozygous $\mathrm{Fgfr}^{\text {ach }}$ transgene. Due to the unavailability of a sufficient number of wild-type FVB/NJcl mice, we used C57BL/6 J wild-type mice to investigate the tissue concentration of meclozine. All experimental procedures were approved by the Animal Care and Use Committee at our institution.

\section{Foramen Magnum Measurements}

Seventeen-day-old wild-type mice and mutant mice were subjected to micro-CT scanning $(0.5-\mathrm{mm} \mathrm{Al}$ filter, $50 \mathrm{kV}, 500 \mu \mathrm{A}$ for 0.054 seconds; SkyScan 1176, Bruker). Three-dimensional images from the CT scan were reconstructed by an in-house volume-rendering software. ${ }^{6}$ This software enabled us to render 3D views of the CT scan from arbitrary viewpoints and view directions as well as to measure the distance between 2 specific points. The areas of the foramen magnum were measured on reconstructed 3D images.

\section{Maternal Administration of Meclozine}

We previously demonstrated that the average plasma concentration of meclozine was $36.58 \pm 20.12 \mathrm{ng} / \mathrm{ml}( \pm$ $\mathrm{SD}, \mathrm{n}=10$ ) after intake of a $0.4 \mathrm{~g} / \mathrm{kg}$ diet, ${ }^{3}$ which was below the mean peak drug concentration of $68.42 \mathrm{ng} / \mathrm{ml}$ after a single dose of $25 \mathrm{mg}$ meclozine tablet in humans. ${ }^{13}$ According to our previous study, food containing meclozine was prepared by mixing $0.4 \mathrm{~g}$ of meclozine with $1 \mathrm{~kg}$ of food (Oriental Yeast Co.). Wild-type female mice were mated with $F g f r 3^{\text {ach }}$ male mice to produce normal and heterozygous mutant embryos. The pregnant mice were then randomly treated with meclozine from embryonic Day (ED) 14.5 to postnatal Day (PD) 4.5. The offspring were divided into 4 groups for each kinship: 1) meclozine-treated $F g f r 3^{\text {ach }}$ mice, 2) meclozine-treated wild-type mice, 3) untreated $\mathrm{Fgfr} 3^{\text {ach }}$ mice, and 4) untreated wild-type mice (Fig. 1).

\section{Skeletal Preparation}

Whole skeletons were harvested on PD 4.5 and stored in $90 \%$ ethanol for 3 days, followed by acetone treatment for 2 days. ${ }^{12}$ Specimens were then stained using Alizarin red to analyze ossified bones and Alcian blue to analyze 
cartilage for 3 days at $37^{\circ} \mathrm{C}$. Following incubation, the samples were transferred to $1 \% \mathrm{KOH}$ and incubated at room temperature for 2 days. The specimens were serially washed with decreasing concentrations (1\% to $0 \%$ ) of $\mathrm{KOH}$ and increasing concentrations ( $0 \%$ to $100 \%)$ of glycerol by monitoring the intensity of the stain and the amount of tissue remaining on the specimens. Craniums were dissected under the microscope.

\section{Histological Evaluation of the Synchondroses at the Cranial Base}

The bony bridges of a spheno-occipital synchondrosis and 2 anterior intraoccipital synchondroses were histologically examined after being stained with Alizarin red and were scored according to 4 separate appearances (nonbridge, 0 points; minimal bony bridge, 1 point; incomplete bony bridge, 2 points; complete bony bridge, 3 points). Therefore, the maximum bony bridge score was 9 .

\section{Measurements of Tissue Meclozine Concentration}

After maternal ad libitum feeding of meclozine $(0.4 \mathrm{~g} /$ $\mathrm{kg}$ diet) for 72 hours, ED 17.5 and PD 6.5 of C57BL/6 J mice were euthanized under deep anesthesia, and tissue concentrations of meclozine in the entire body were measured for evaluation of transmission of meclozine through the placenta and milk, respectively (Tanabe R\&D Service Co.).

\section{Statistical Analysis}

Statistical analyses were carried out using the unpaired Student t-test. Data are expressed as the mean \pm SD.

\section{Results}

\section{Foramen Magnum Stenosis}

We measured the area of the foramen magnum using reconstructed 3D images from micro-CT scanning in wild-type mice and $F g f r 3^{\text {ach }}$ mice at PD 17 . The area of the foramen magnum was significantly decreased in $\mathrm{Fg} f r 3^{\text {ach }}$ mice $\left(10.58 \pm 0.42 \mathrm{~mm}^{2}\right)$ compared with wild-type mice $\left(12.97 \pm 0.36 \mathrm{~mm}^{2}\right)(\mathrm{p}<0.005)$ (Fig. 2).

\section{Closure of Synchondroses}

We next evaluated the effect of meclozine on synchondrosis closure at the cranial base in PD 4.5 mice. Sphenooccipital and anterior intraoccipital synchondroses were always cartilaginous in wild-type mice, whereas there were some bony bridges within these synchondroses in $F g f r 3^{\text {ach }}$ mice. We analyzed a total of 19 kinships, including 16 meclozine-treated $F g f r 3^{\text {ach }}$ mice and 19 untreated $\mathrm{Fgfr}^{\text {ach }}$ mice. Premature closure of occipital synchondroses was inhibited by meclozine treatment in some $\mathrm{Fgfr} 33^{\text {ach }}$ mice (Fig. 3). The average bony bridge score at the cranial base, however, was $7.053 \pm 1.393$ in untreated $F g f r 3^{\text {ach }}$ mice and $6.125 \pm 2.029$ in meclozine-treated $F g f r 3^{\text {ach }}$ mice, which was not statistically significant $(\mathrm{p}=0.12)($ Fig. 4).

\section{Placental Transmission of Meclozine}

We next examined the tissue concentrations of meclozine in ED 17.5 and PD 6.5 wild-type mice after maternal
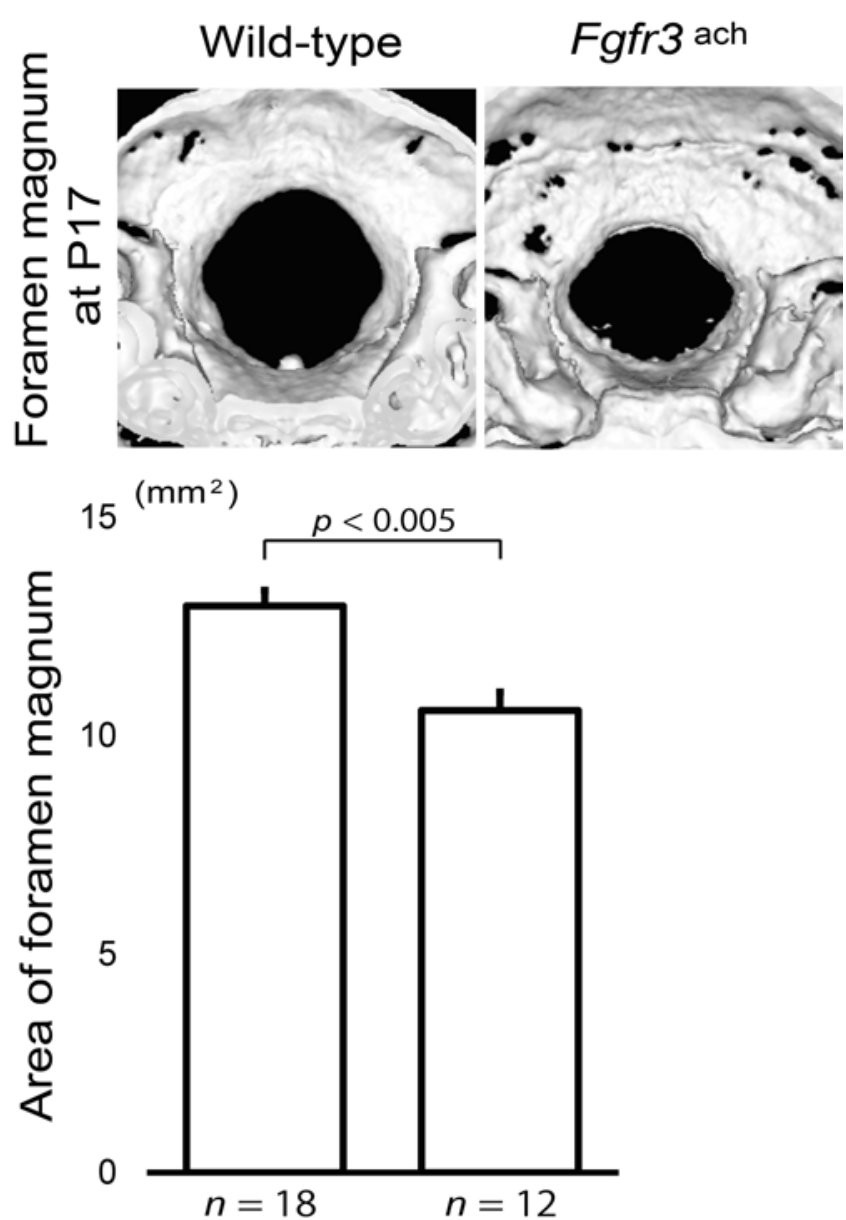

FIG. 2. Reconstructed 3D images of the cranial base from intracranial view. FMS was evident in 17-day-old Fgfr ${ }^{\text {ach }}$ mice. Statistical significance was analyzed using the unpaired t-test. P17 = postnatal Day 17.

administration. Both the placental and breast milk transportability was confirmed by measurements of meclozine concentration in homogenized embryos and infants. The average tissue concentration of meclozine was 56.91 $\pm 20.05 \mathrm{ng} / \mathrm{g}$ in ED 17.5 mice and $508.88 \pm 205.16 \mathrm{ng} / \mathrm{g}$ in PD 6.5 mice, indicating that placental transmission of meclozine was likely to be approximately 9 times less than that of breast milk transmission (Fig. 5).

\section{Discussion}

FMS is a devastating and life-threatening complication during early infancy in patients with $\mathrm{ACH}$. In our previous study, we could not prevent FMS by administration of meclozine to 21- to 42-day-old Fgfr $3^{\text {ach }}$ mice, although the longitudinal bone lengths increased. ${ }^{3}$ Similarly, subcutaneous administration of BMN-111, in 7- to 17-day-old Fgfr $3^{\mathrm{Y} 367 \mathrm{C} /+}$ mice did not increase the sagittal and lateral diameters of the foramen magnum. ${ }^{2}$ In the present study, we found that premature closure of synchondroses at the cranial base began to develop in 4.5-day-old mutant mice, and FMS was evident in 17-day-old mutant mice. Maternal administration of an FGFR3-inhibiting drug, therefore, is indispensable to prevent premature closure of occipital synchondroses and FMS. 


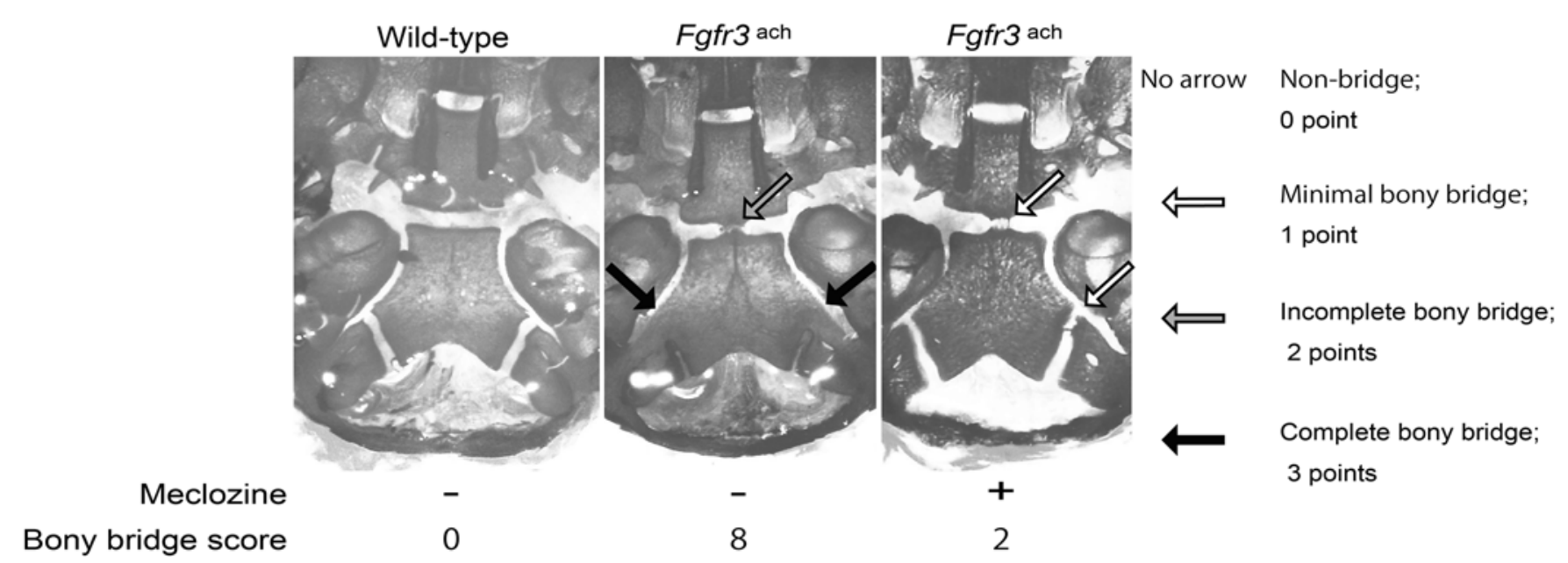

FIG. 3. Representative Alizarin red staining of the cranial base of wild-type and transgenic mice on PD 4.5. Bony bridges were rated from 0 to 3 points. No bony bridge was observed in wild-type mice, while premature synchondrosis closure was observed in untreated Fgfr3ach mice.

We previously demonstrated that maternal administration of meclozine from ED 14.5 to PD 4.5 increased longitudinal bone length in wild-type mice by $1.6 \%$ to $4.3 \%$ on PD 4.5 after adjusting litter size. The lengths of the ulna, femur, and tibia were significantly increased after meclozine treatment, while no statistically significant differences were seen in the lengths of the humerus and radius. ${ }^{3}$ Maternal administration from ED 14.5 to PD 4.5 showed

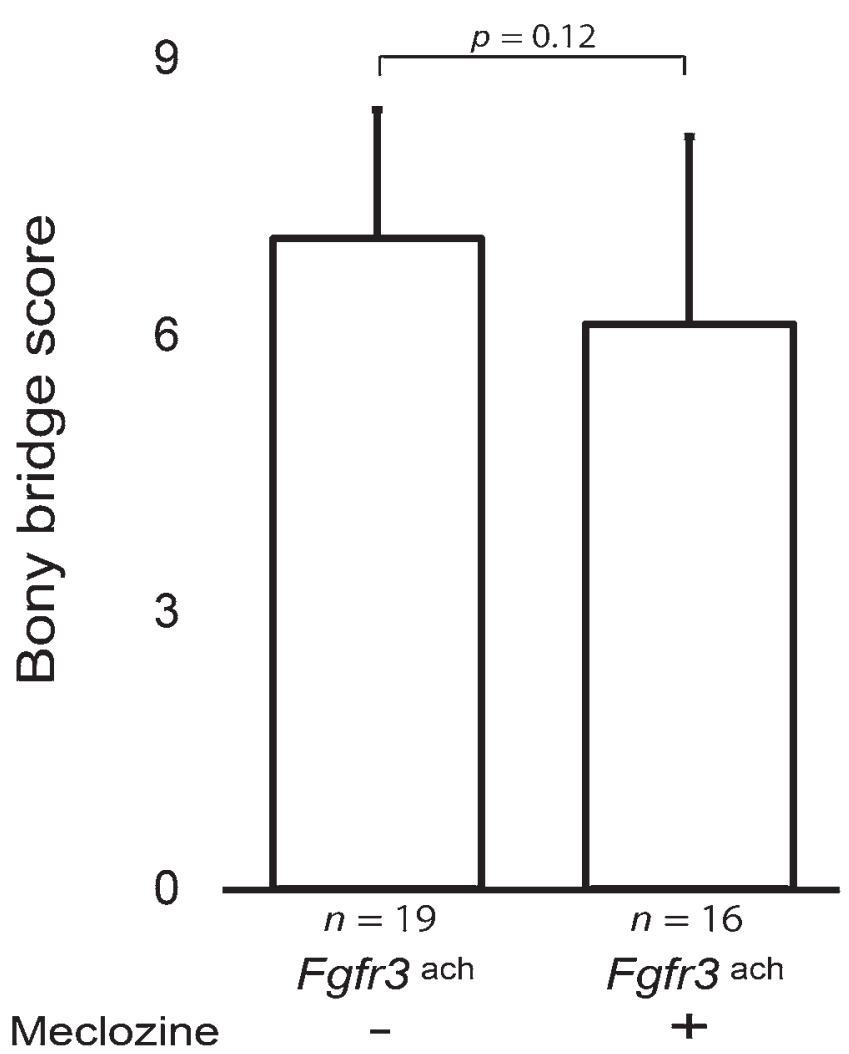

FIG. 4. Quantification of the bony bridge score in the cranial base of Fgfr3ach mice. Meclozine decreased the bony bridge score, although there was no statistically significant difference (unpaired t-test). less effect on longitudinal bone growth than oral administration to the growing pups from PD 21 to PD 42. In the present study, we could not show significant effects of maternal administration of meclozine on premature closure of synchondroses in the cranial base at PD 4.5. Limited effects of prenatal treatment of meclozine on suppression of FGFR3 signaling may be due to its relatively low pla-

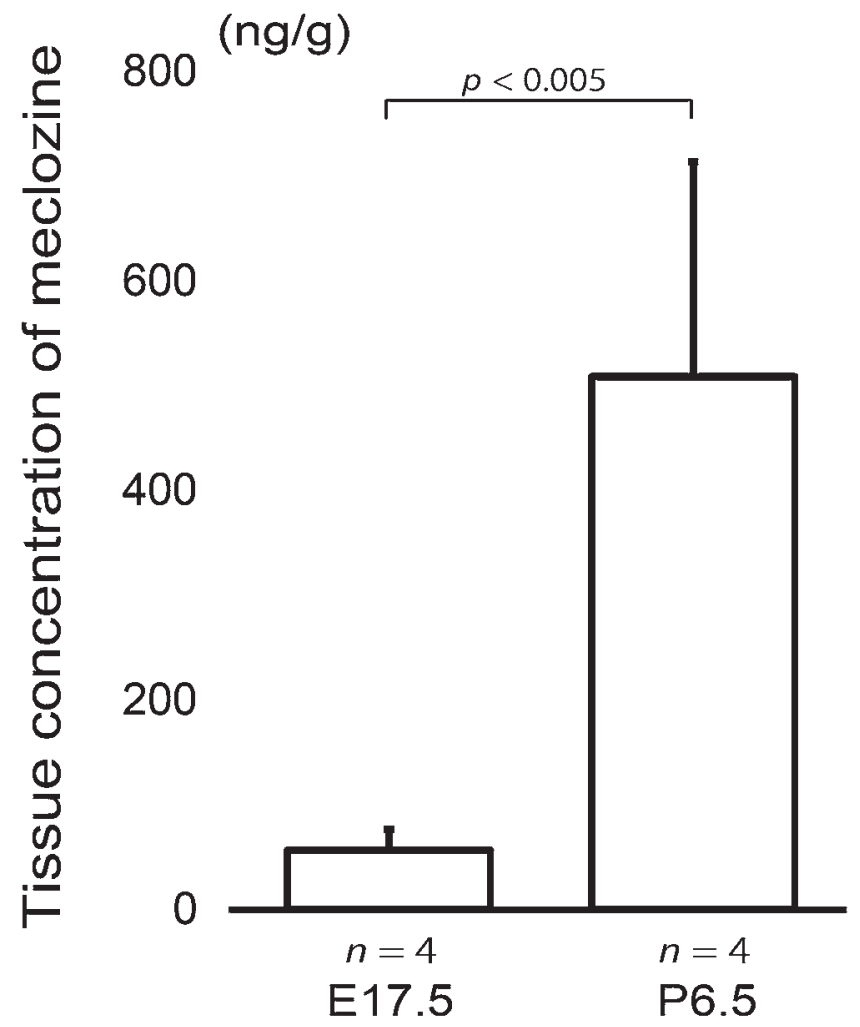

FIG. 5. Tissue concentration of meclozine in ED 17.5 (E17.5) and PD 6.5 (P6.5) offspring after maternal administration for 72 hours. The meclozine concentration was significantly lower in the ED 17.5 offspring than in the PD 6.5 offspring. Statistical significance was analyzed using the unpaired t-test. 
cental transmission. A higher dose of meclozine during the prenatal period would be necessary for the treatment of FMS in ACH, although teratogenicity and adverse effects of maternally administrated meclozine would be of concern in clinical feasibility of this drug.

There are several limitations in the current study. We could not adjust the litter size of $F g f r 3^{\text {ach }}$ mice, which was different from mother to mother. In addition, the amount of breast milk intake might be different among mutant offspring, since some mutant mice were suffering from maternal neglect. The method of administration is another limitation. Pharmaceutical activity of meclozine within foods could be decreased over time. Further studies are needed to investigate the optimal dose of meclozine for the treatment of FMS in ACH.

\section{Conclusions}

The effect of maternal administration of meclozine on prevention of premature synchondrosis closure at the cranial base was not significant, probably due to low placental transmission of the drug.

\section{Acknowledgments}

We thank Dr. David M. Ornitz at Washington University in St. Louis for providing $F g f r 3^{\text {ach }}$ mice.

\section{References}

1. Hecht JT, Horton WA, Reid CS, Pyeritz RE, Chakraborty R: Growth of the foramen magnum in achondroplasia. Am J Med Genet 32:528-535, 1989

2. Lorget F, Kaci N, Peng J, Benoist-Lasselin C, Mugniery E, Oppeneer T, et al: Evaluation of the therapeutic potential of a CNP analog in a Fgfr3 mouse model recapitulating achondroplasia. Am J Hum Genet 91:1108-1114, 2012

3. Matsushita M, Hasegawa S, Kitoh H, Mori K, Ohkawara B, Yasoda A, et al: Meclozine promotes longitudinal skeletal growth in transgenic mice with achondroplasia carrying a gain-of-function mutation in the FGFR3 gene. Endocrinology 156:548-554, 2015

4. Matsushita M, Kitoh H, Ohkawara B, Mishima K, Kaneko H, Ito $\mathrm{M}$, et al: Meclozine facilitates proliferation and differentiation of chondrocytes by attenuating abnormally activated FGFR3 signaling in achondroplasia. PLoS One 8:e81569, 2013

5. Matsushita T, Wilcox WR, Chan YY, Kawanami A, Bükülmez $\mathrm{H}$, Balmes $\mathrm{G}$, et al: FGFR3 promotes synchondrosis closure and fusion of ossification centers through the MAPK pathway. Hum Mol Genet 18:227-240, 2009

6. Mori K, Suenaga Y, Toriwaki J: Fast software-based volume rendering using multimedia instructions on PC platforms and its application to virtual endoscopy. Proc SPIE 5031:111122,2003

7. Naski MC, Colvin JS, Coffin JD, Ornitz DM: Repression of hedgehog signaling and BMP4 expression in growth plate cartilage by fibroblast growth factor receptor 3. Development 125:4977-4988, 1998

8. Pauli RM: Surgical intervention in achondroplasia. Am J Hum Genet 56:1501-1502, 1995

9. Pauli RM, Scott CI, Wassman ER Jr, Gilbert EF, Leavitt LA, Ver Hoeve J, et al: Apnea and sudden unexpected death in infants with achondroplasia. J Pediatr 104:342-348, 1984

10. Rousseau F, Bonaventure J, Legeai-Mallet L, Pelet A, Rozet JM, Maroteaux P, et al: Mutations in the gene encoding fibroblast growth factor receptor-3 in achondroplasia. Nature 371:252-254, 1994

11. Shiang R, Thompson LM, Zhu YZ, Church DM, Fielder TJ, Bocian M, et al: Mutations in the transmembrane domain of FGFR3 cause the most common genetic form of dwarfism, achondroplasia. Cell 78:335-342, 1994

12. Wallin J, Wilting J, Koseki H, Fritsch R, Christ B, Balling R: The role of Pax-1 in axial skeleton development. Development 120:1109-1121, 1994

13. Wang Z, Lee B, Pearce D, Qian S, Wang Y, Zhang Q, et al: Meclizine metabolism and pharmacokinetics: formulation on its absorption. J Clin Pharmacol 52:1343-1349, 2012

14. Yamashita A, Morioka M, Kishi H, Kimura T, Yahara Y, Okada M, et al: Statin treatment rescues FGFR3 skeletal dysplasia phenotypes. Nature 513:507-511, 2014

15. Yasoda A, Kitamura H, Fujii T, Kondo E, Murao N, Miura $\mathrm{M}$, et al: Systemic administration of C-type natriuretic peptide as a novel therapeutic strategy for skeletal dysplasias. Endocrinology 150:3138-3144, 2009

\section{Disclosures}

The authors report no conflict of interest concerning the materials or methods used in this study or the findings specified in this paper.

\section{Author Contributions}

Conception and design: Matsushita. Acquisition of data: Matsushita, Esaki. Analysis and interpretation of data: Matsushita, Esaki. Drafting the article: Matsushita, Ohno. Critically revising the article: Kitoh, Matsushita, Ishiguro, Ohno. Reviewed submitted version of manuscript: Kitoh, Matsushita, Ishiguro, Ohno. Approved the final version of the manuscript on behalf of all authors: Kitoh. Statistical analysis: Matsushita. Administrative/ technical/material support: Mishima, Esaki. Study supervision: Kitoh, Mishima, Ishiguro, Ohno.

\section{Correspondence}

Hiroshi Kitoh, Department of Orthopaedic Surgery, Nagoya University Graduate School of Medicine, 65 Tsurumai, Showa-ku, Nagoya 466-8550, Japan. email: hkitoh@med.nagoya-u.ac.jp. 